\title{
Mineralogy and genesis of Kutinga manganese deposit, South Orissa, India
}

\author{
B.C. ACHARYA, D.S. RAO \\ and R.K. SAHOO \\ Regional Research Laboratory, (CSIR) \\ Bhubaneswar-751 013, Orissa, India
}

\begin{abstract}
Manganese ores at Kutinga occur as distinctly conformable bands in the khondalite suit of rocks of Eastern Ghats complex. The dominant manganese ore minerals include cryptomelane, psilomelane, pyrolusite, hausmannite, lithiophorite and wad. Quartz, chalcedony, orthoclase, garnet and kaclinite are the associated gangue minerals. Presence of high iron, high phosphorous, low to medium silica and dominance of $\mathrm{CaO}$ over $\mathrm{MgO}, \mathrm{K}_{2} \mathrm{O}$ over $\mathrm{Na}_{2} \mathrm{O}$, Ni over $\mathrm{Co}, \mathrm{Zn}$ over $\mathrm{Pb}$ and $\mathrm{Cu}$ over $\mathrm{Pb}$ are the characteristics of this manganese deposit. Phosphorous occurs as discrete apatite inclusions within the quartz and orthoclase; and also adsorbed in the secondary manganese and iron minerals. Field characters, mineralogy and geochemistry of manganese ores suggest their formation as chemical precipitates, and the source of which appears to be continental erosion. Manganese formation along with the country rocks have been metamorphosed under granulite facies conditions, affected by granitisation and subsequently undergone supergene enrichment to give rise to the present deposit. These ores will be amenable to removal of silica, but will not respond well to removal of iron and phosphorous by physical beneficiation.
\end{abstract}

Keywords: Eastern Ghats complex, India, Manganese, Phosphorous, Mineral chemistry, Geochemistry, Genesis

\section{Introduction}

India has a total reserve of 176 million metric tonnes of manganese ore, but most of it is either low or off grade ore, due to the presence of high amounts of iron and/or phosphorous. Around $95 \%$ of manganese ore in India is utilised in iron and steel industries (Indian Minerals Year Book, 1990). Orissa accounts for about 41 million metric tonnes manganese ores associated with Iron Ore Group of north Orissa and Eastern Ghats complex of south Orissa, of which about one third of the reserves are in latter association. The manganese deposits of south Orissa are considered to be the extensions of "Koduritic types" (manganese deposits associated with high grade meta- morphic terrain, where manganese oxides were considered to have been derived as alteration product of manganese rich rock containing quartz, potash-feldapar, garnet, manganesepyroxene and apatite termed Kodurite) of $\mathrm{Vi}$. shakhapatnam and Srikakulam districts of Andhra Predesh (Fermor, 1909; Roy, 1981), and are rich in phosphorous, on an average containing $0.3 \%$ of phosphorous (Mohanty, 1991) and as such are not suitable for even in iron and steel industries. Presence of high amounts of phosphorous in manganese ores deteorates the mechanical properties of steel. An attempt is made in this paper to decipher the mineralogy, chemistry, and modes of occurrence of phosphorous, iron and silica which will throw light on its genesis as well as the amenability of the ore 

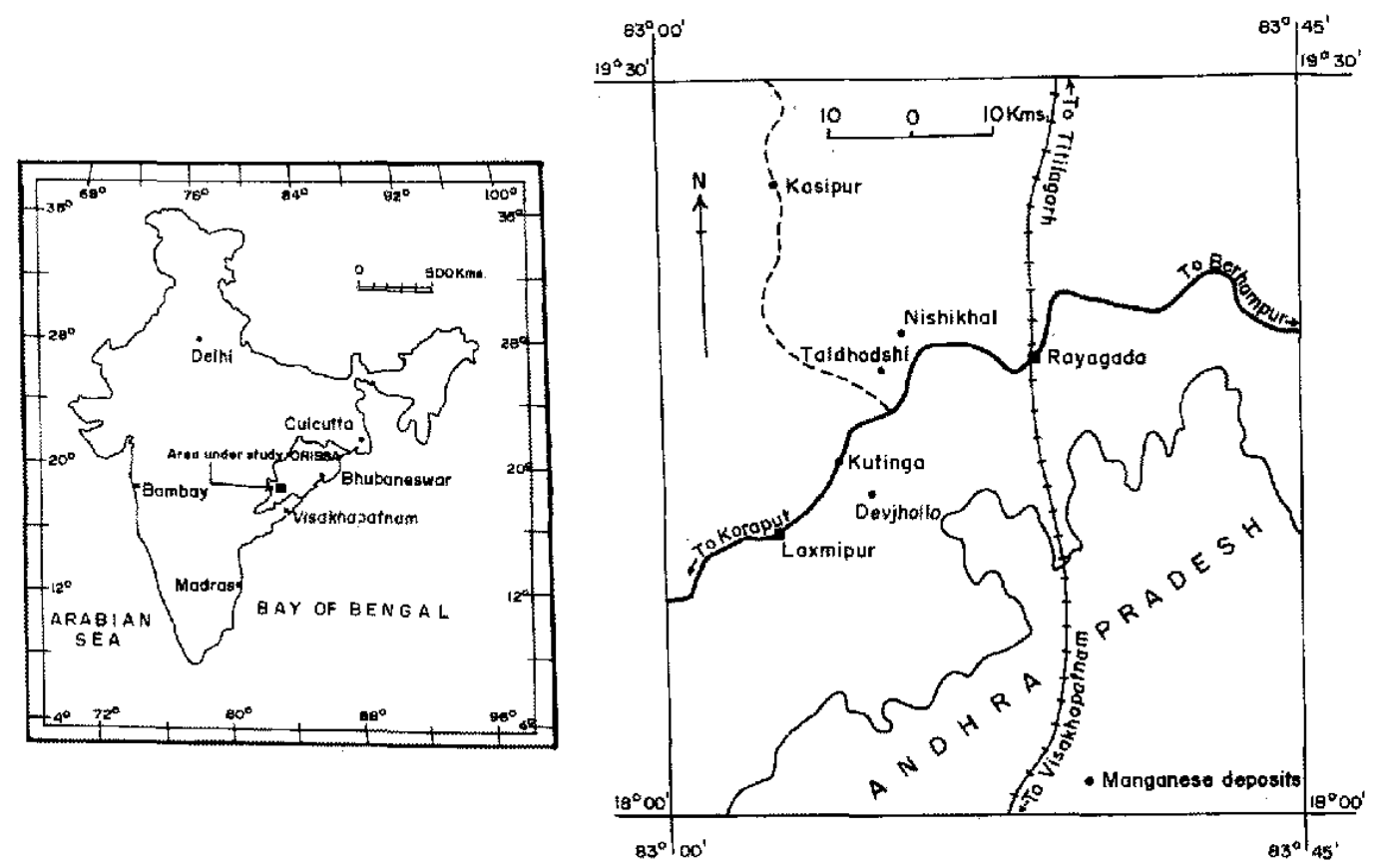

Fig. 1. Location and index map, showing Kutinga and other manganese deposits in parts of South Orissa.

to beneficiation.

\section{Geological setting}

A number of manganese deposits (e.g. Deviholla, Podkana, Taldohdshi, Nishikhal, Kasipur and Kutinga) form a small manganese belt trending NNE-SSW over a strike length of about 40 kilometers in the Eastern Ghats complex. The manganese deposit at Kutinga (Lat. $19^{\circ} 2^{\prime}-19^{\circ} 7^{\prime} \mathrm{N}$ and $83^{\circ} 7^{\prime} 30^{\prime \prime}-83^{\circ} 12^{\prime} \mathrm{E}$ Long., Fig. 1) is one of the prominent deposits of south Orissa, situated at a distance of 36 kilometers from Rayagada railway station. The deposit occurs in Precambrian Eastern Ghats complex (>2600 million years), associated with metasedimentary rock types such as khondalite, quartzite and manganiferous quartzite. Calc-silicate granulite is also reported from this area. The ore body is parallel to foliation planes of migmatised khondalite and quartzite. These rock types along with the manganese ore band form more or less banded assemblage, metamorphosed under granulite facies condition (quart $z \sim$ orthoclase-garnet-sillimanitegranulite), and are permeated by quartz-feldspar neosomes and pegmatites (Fig. 2) and have experienced all the granitisational and deformational episodes of Eastern Ghats orogeny. The general strike is NNE-SSW with a steep to vertical dip. The strike swings from NESW to NS to even NW-SE locally.

\section{Mineralogy}

Mineralogical studies (supplemented by XRay Diffraction pattern) on manganese ores from Kutinga revealed the presence of primary as well as secondary minerals. Hausmannite and spessartite are the only primary manganese minerals recorded. Cryptomelane, psilomelane, pyrolusite and lithiophorite are the secondary manganese minerals identified whereas quartz, chalcedony, orthoclase, garnet, 


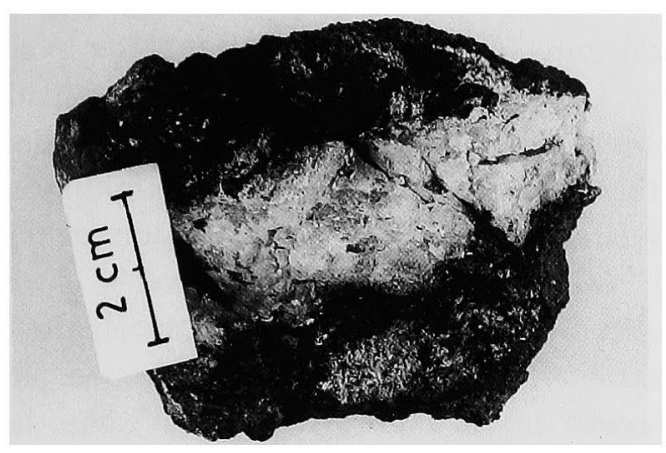

Fig. 2. Quartz-feldspar pegmatite (white) is associated with manganese ore (black).

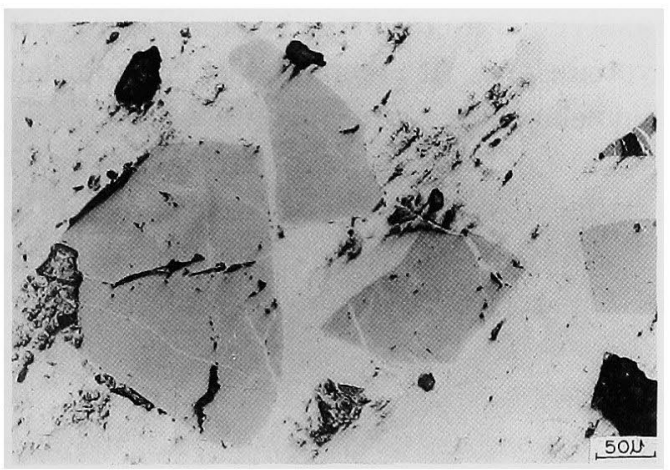

Fig. 3. Hausmannite grains (dark grey) enclosed within cryptomelane. Replacement of hausmannite by cryptomelane is distinct.

kaolinite, apatite, sphene, biotite and zircon form the silicate gangue minerals. Associated opaque minerals include goethite and graphite with traces of hematite and pyrite.

Hausmannite is present as subhedral to anhedral grains within a groundmass of cryptomelane/psilomelane. Twinning in hausmannite is very common, lamellae often intersecting each other. Cryptomelane and psilomelane replace hausmannite along margin and enclose unreplaced islands (Fig. 3). Cryptomelane is very fine-grained and mostly occurs as colloform bands along with psilomelane, goethite and/or pyrolusite (Figs. 4-6). Replacement of psilomelane by cryptomelane and vice versa has been observed.

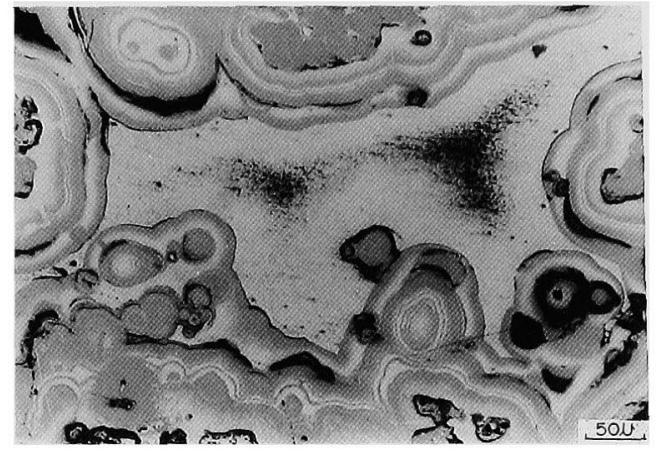

Fig. 4. Cryptomelane (light grey), psilomelane (dark grey) exhibit olloform bands.

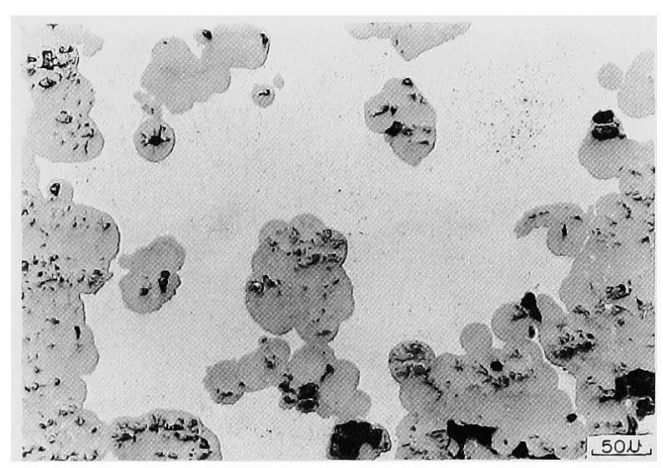

Fig. 5. Pisolitic texture of psilomelane (dark grey) associated with cryptomelane (light grey).

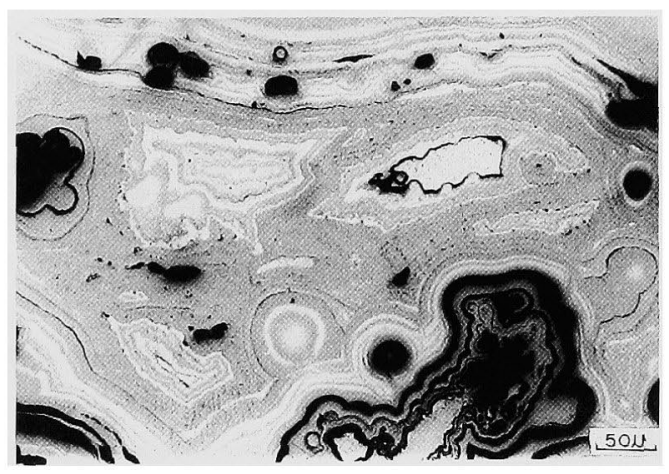

Fig. 6. Cryptomelane (light grey), goethite (dark grey) and pyrlouiste (whitish) are interlayered and exhibit colloform bands. Oxy-hydroxides of iron-manganese (dark grey to black) is at the left bottom corner. 


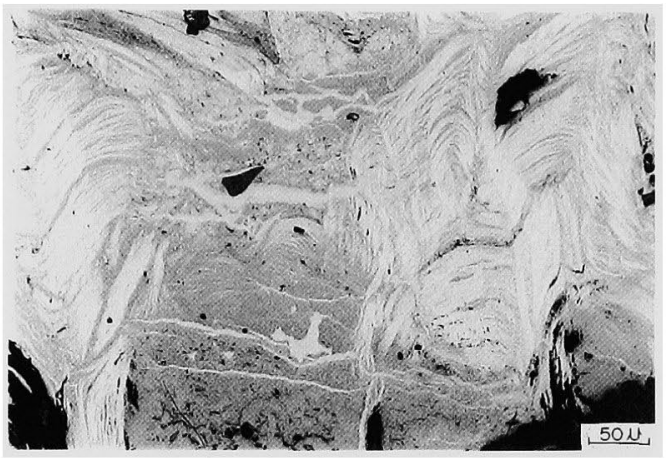

Fig. 7. Pyrolusite (light grey) exhibits branching, kinking and micro-veins in psilomelane (dark grey).

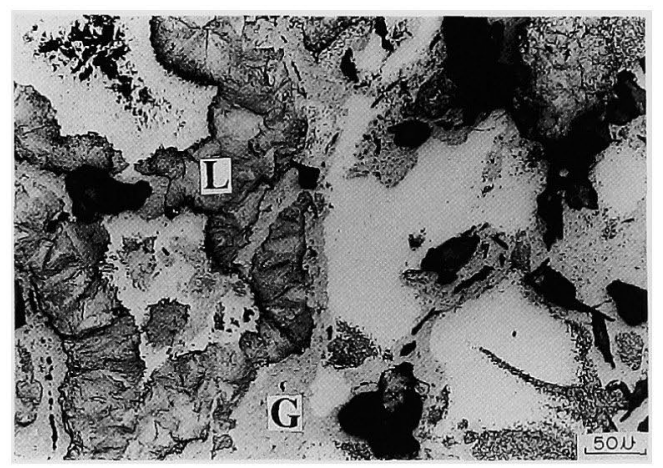

Fig. 8. Lithiophorite ( $\mathrm{L}$; showing strong reflection pleochroism) associated with goethite $(\mathrm{G})$ and cryptomelane (white).

This indicates their simultaneous formation. At places thin veins of cryptomelane cut across psilomelane, goethite and earlier formed cryptomelane, suggesting two stages of cryptomelane development. Cryptomelane as well as psilomelane are present in bortryoidal manganese ores and show colloform, oolitic and pisolitic texture. In botryoidal ores psilomelane also shows mammilary texture. Pyrolusite is present as cryptocrystalline bands interlayered with cryptomelane/psilomelane or goethite. It is also present as stout crystals exhibiting strong reflection pleochroism and anisotropism. Pyrolusite replaces cryptomelane, psilomelane and goethite, and contains their unreplaced islands. The replacement boundary between pyrolusite and gangue min erals often shows a saw-teeth texture. Veins of pyrolusite are observed within cryptomelane/psilomelane and fine-grained lithiophorite. Branching and kinking of pyrolusite are recorded in rare instances (Fig. 7). Microfolding of pyrolusite veins is also noticed within psilomelane. Lithiophorite is characterised by very strong reflection pleochroism in dark grey to greyish white, low reflectivity, strong anisotropism and mostly occurs as fine-grained aggregates (Fig. 8). It is common in lateritic types but also recorded in massive manganese ores along with cryptomelane. It is replaced by cryptomelane, psilomelane and pyrolusite.

Most of the iron in these manganese ores is contributed by goethite and is intimately associated with manganese phases. It occurs either as colloform bands or in oolitic, pisolitic forms within cryptomelane and psilomelane. Scales, flakes and tablets of graphite are noticed along the grain boundaries and intergranular spaces of gangue minerals. Cryptomelane, psilomelane and goethite replace graphite along cleavage and kink planes and enclose flakes and tablets within them (Figs. 9-10). Branching in graphite enclosing silicate minerals is common. Graphite is curved, kinked and folded.

Quartz, chalcedony, orthoclase, garnet, kaolinite, apatite with traces of biotite, sphene and zircon are the gangue minerals associated in these ores. Many of the quartz and orthoclase grains show undulose extinction, indicating effect of stress. Chalcedony shows fibrous structure, some times sheaf-like aggregates, leafy aggregates or spherulitic (Fig. 11) and colloform texture. It is replaced by manganese minerals along grain margins and fractures. Replacement of quartz and orthoclase by secondary manganese minerals (Figs. 12-13) is noticed along grain boundaries, cleavage and 


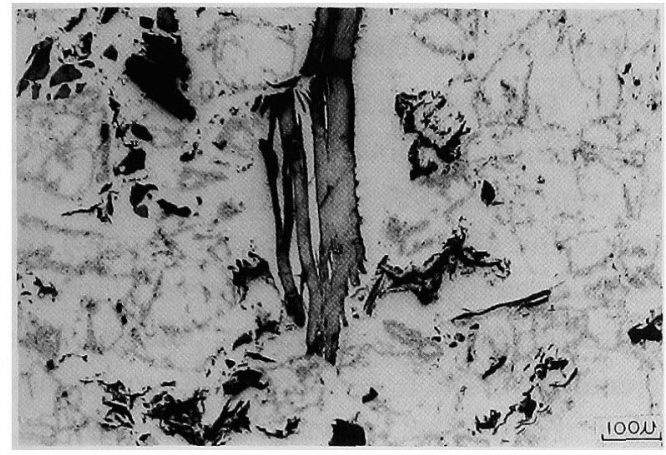

Fig. 9. Cryptomelane (light grey) replaces graphite flakes along margin and cleavage planes and encloses within it. Goethite (dark grey) is very intricately intergrown with cryptomelane.

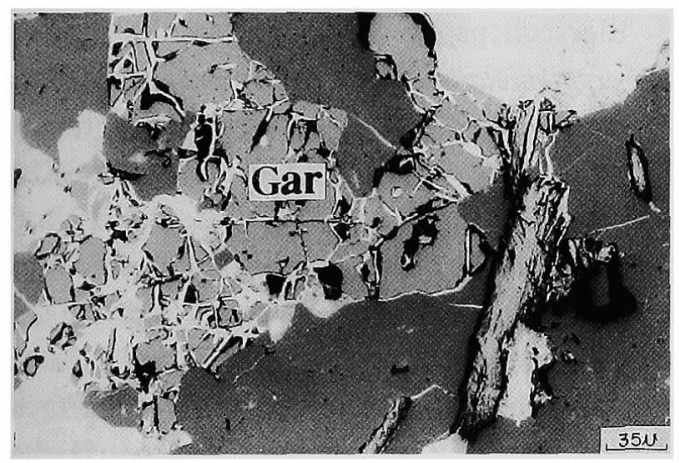

Fig. 10. Flakes and scales of graphite in silicate gangue minerals (dark grey) associated with cryptomelane (white) and garnet (Gar). Alteration of garnet along fractures to cryptomelane is very distinct.

fracture planes often resulting in box-work type texture. Apatite, zircon and sphene are found as inclusions within quartz and orthoclase (Fig. 12). Grain size of apatite varies from 3 to 20 microns. Zircon is observed as rounded to subrounded or eliptical grains. Orthoclase has been altered to kaolinite in a number of places. Garnet occurs as subhedral to anhedral grains and present along with quartz and orthoclase. Alteration of garnet is very conspicuous. It proceeds from grain margins, fractures and at times completely alters to biotite, and oxy-hydroxide of manga-

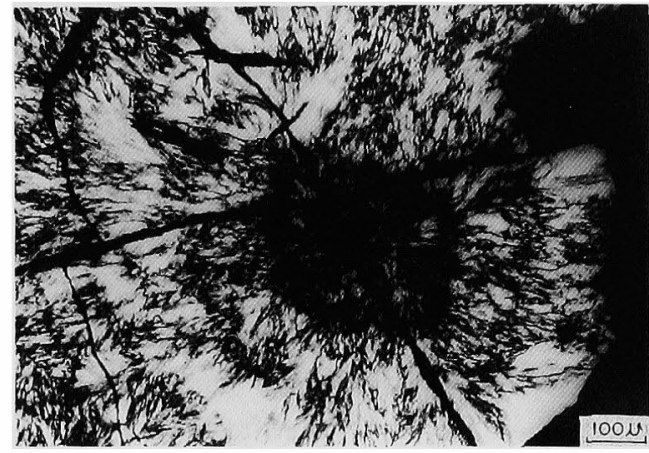

Fig. 11. Chalcedony shows spherulitic texture and is replaced by manganese minerals (black). Transmitted light, under crossed nicols.

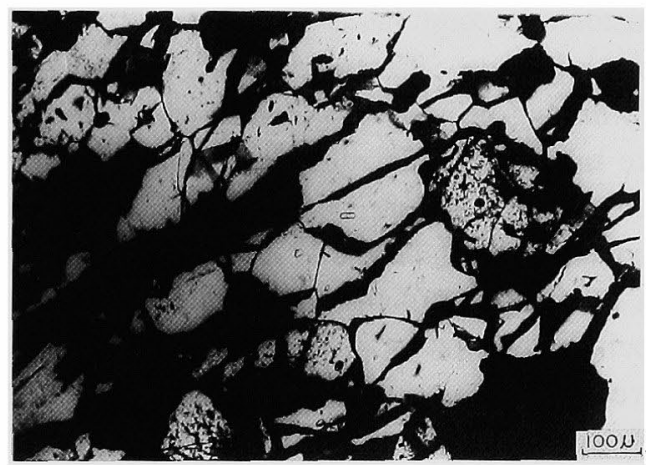

Fig. 12. Quartz and orthoclase are replaced by manganese minerals along grain boundaries and enclosed by managnese minerals (black). Note the fine crystal of apatite within quartz and orthoclase at the centre of the photomicrograph.

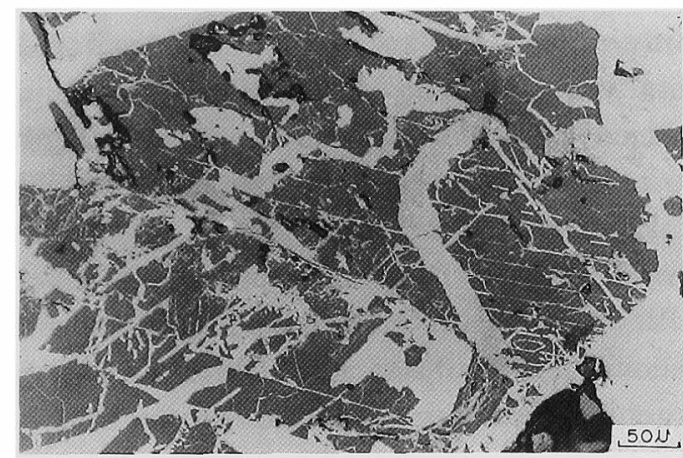

Fig. 13. Cryptomelane (white) replaces a silicate mineral (dark grey) along grain boundaries, fractures and cleavage planes. 
nese-iron, cryptomelane (Fig. 10) and/or goethite.

\section{Mineral paragenesis}

The sequence of mineral formation or paragenesis observed in a mineral deposit helps in the interpretation of ore genesis. An attempt has been made here to establish the paragenesis of different ore and gangue minerals on the basis of their textural relationships. The earliest mineral assemblage (recognisable) belongs to the granulite facies, and is represented by quart $z$ + orthoclase + garnet + hausmannite \pm hematite \pm graphite. Garnet (spessartite), hausmannite and hematite represent the primary minerals. Textural equilibrium relationship among primary manganese oxide and silicate minerals could not be established due to their isolated nature enclosed in a matrix of secondary manganese and iron minerals. During granitisation some amounts of quartz, orthoclase, biotite, apatite and graphite might have also been added. Secondary manganese and iron oxide minerals are formed from the primary minerals by weathering and supergene enrichment. Goethite, cryptomelane, psilonelane, pyrolusite show colloform texture suggesting their simultaneous formation. Possibly there could be two stages of cryptomelane development; the earlier one occurs simultane. ously with psilomelane and the later veins cross cut the psilomelane, goethite and the earlier formed cryptomelane. Later veins of pyrolusite are found to cut across the cryptomelane, psilomelane, goethite and earlier pyrolusite. Pyrolusite II is later to cryptomelane II and both are later to lithiophorite. Cryptomelane, psilomelane, pyrolusite and goethite are later to graphite is evidenced by their presence along the cleavage and kink planes of graphite and the enclosures of graphite within the former minerals. Wad is the latest mineral developed by weathering process.

\section{Mineral chemistry}

A few selected mineral phases (cryptomelane, psilomelane, goethite, garnet and iron-manganese oxide/hydroxide) were analysed by JEOL EPMA Super Probe JXA8600 model with the help of pre-set automatic programmable point scanner using inter. national standrads (minerals of manganese oxides, iron oxides, manganese silicates etc.), with an accelerating voltage of $15 \mathrm{kV}$ and a specimen current of $2 \times 10^{-8} \mathrm{~mA}$. On line ZAF correction procedure was adopted. Electron probe data along with their structural formulae are presented in Table 1.

Electron probe analytical results indicate that cryptomelane is essentially potassium bearing manganese oxide, on an average containing $94.58 \% \mathrm{MnO}_{2}, 4.33 \% \mathrm{~K}_{2} \mathrm{O}$ and traces of $\mathrm{SiO}_{2}$, $\mathrm{Al}_{2} \mathrm{O}_{3}, \quad \mathrm{Fe}_{2} \mathrm{O}_{3}, \quad \mathrm{TiO}_{2}, \quad \mathrm{P}_{2} \mathrm{O}_{5}, \mathrm{CaO}$ and $\mathrm{Na}_{2} \mathrm{O}$. Small quantities of $\mathrm{MgO}$ and $\mathrm{BaO}$ are recorded in some cases. High amounts of $\mathrm{P}_{2} \mathrm{O}_{5}$ is detected in cryptomelane. $\mathrm{Ba}$ and $\mathrm{Na}$ in cryptomelane may be due to substitution for $\mathrm{K}$, while $\mathrm{Al}$ and $\mathrm{Fe}$ substitute for Mn. Higher amounts of barium and lower potassium distinguishes psilomelane from cryptomelane. It contains less $\mathrm{P}_{2} \mathrm{O}_{5}(0.21 \%)$ and more $\mathrm{Al}_{2} \mathrm{O}_{3}$ than cryptomelane. Gocthite analyses show uniform $\mathrm{Fe}_{2} \mathrm{O}_{3}$ content with variation in $\mathrm{MnO}_{2}$, $\mathrm{SiO}_{2}$ and $\mathrm{Al}_{2} \mathrm{O}_{3} . \mathrm{CaO}, \mathrm{MgO}$ and $\mathrm{BaO}$ are in minor traces. It contains significant amount of $\mathrm{P}_{2} \mathrm{O}_{5}(0.64$ to $1.62 \%)$. The phosphorous content in goethite may be due to adsorption or chemisorption (Mookherjee, 1961 ; Acharya et al., 1990) or in solid solution (Graham, 1973). Goethite has the ability to accept phosphorous into solid solution as the structure is based on a closed packed hydroxy (oxygen) lattice, in which the tetrahedral interstices are of suitable size to accommodate the phosphorous ion, and the charges could be balanced by converting some hydroxyl to oxygen when phosphorous is 
Table 1. Electron probe analyses of cryptomelane, psilomelane, goethite, garnet and oxy-hydroxide of iron and manganese

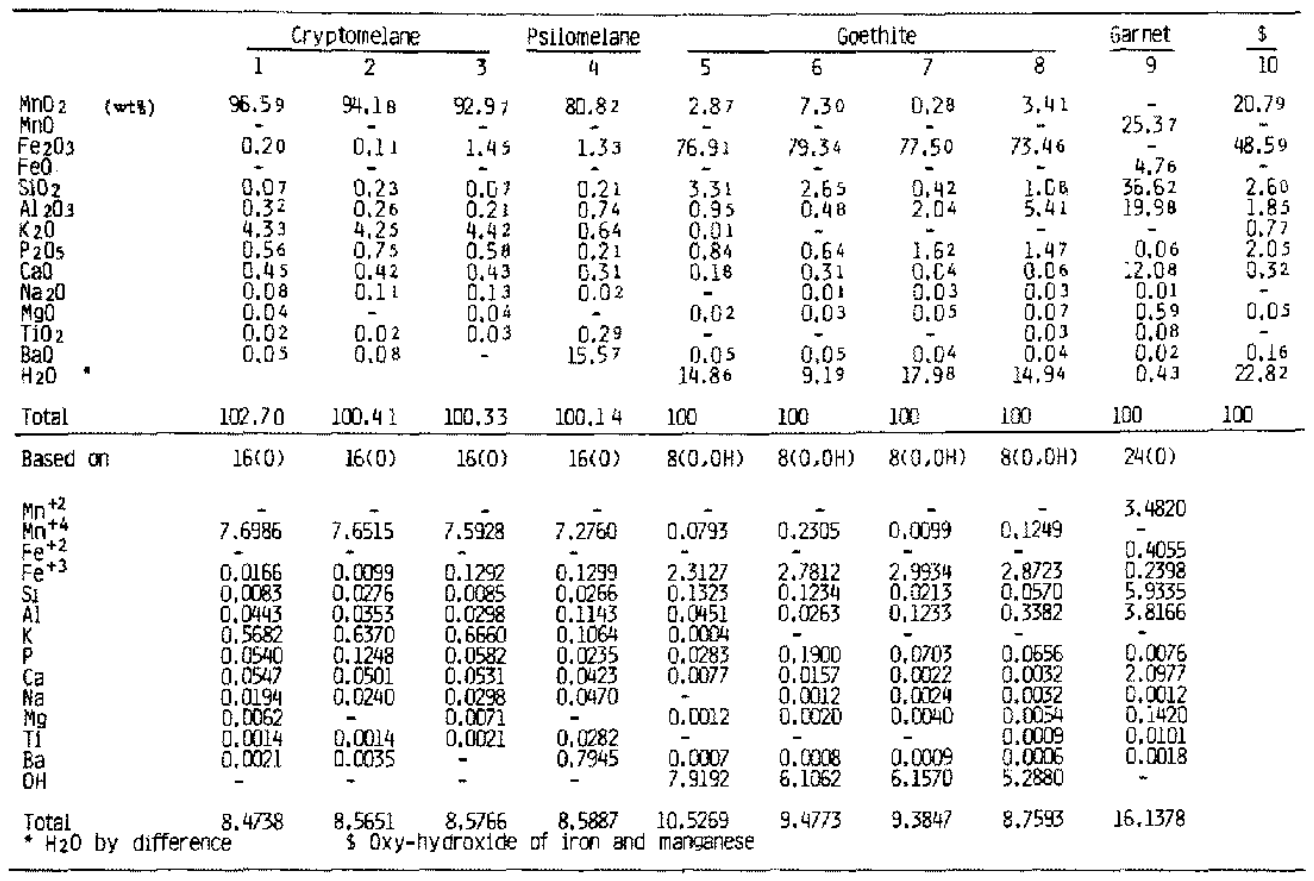

added. Manganese is mostly present substituting for iron, whereas silica may be due to admixtures and/or impurity (Deer et al., 1963). Other trace elements like $\mathrm{Na}, \mathrm{K}$, Ti are present in some analysis and absent in others.

Garnet analysis reveals that it is dominantly a spessartite, having end member composition of 54.60 mole\% spessartite, 32.92 mole\% grossularite, 3.92 mole $\%$ andradite, 6.36 mole\% almandine, and 2.23 mole\% pyrope. The presence of phosphorous in garnet may be due to replacement of $\mathrm{SiO}_{4}$ group by $\mathrm{PO}_{4}$ (Deer et al., 1963). The analysis of oxy-hydroxide of ironmanganese phase indicates that it is essentially constituted of iron, manganese and water with minor amounts of $\mathrm{SiO}_{2}, \mathrm{Al}_{2} \mathrm{O}_{3}, \mathrm{P}_{2} \mathrm{O}_{3}$ and traces of $\mathrm{K}_{2} \mathrm{O}, \mathrm{CaO}, \mathrm{MgO}$ and $\mathrm{BaO}$. It contains highest amount of phosphorous $\left(2.05 \% \mathrm{P}_{2} \mathrm{O}_{5}\right)$ amongst mineral phases analysed.

\section{Geochemistry}

Major, minor and trace elements of eight samples were analysed in duplicate and the average values are reported in Table 2. Major elements are analysed by conventional wet chemical methods; $\mathrm{K}_{2} \mathrm{O}, \mathrm{Na}_{2} \mathrm{O}, \mathrm{CaO}$ and $\mathrm{Li}_{2} \mathrm{O}$ were analysed by Flame photometer (Systronics, model K-III) ; $\mathrm{P}_{2} \mathrm{O}_{5}$ by colorimeter (Systronics) following Vogel (1961) and trace elements ( $\mathrm{Cu}, \mathrm{Ni}, \mathrm{Co}, \mathrm{Zn}, \mathrm{Pb}$ and $\mathrm{Cr}$ ) were done by Varian Tectron AA-1475 ABD Atomic Absorption Spectrophotometer. In case of major elements there was excellent agreement between the values. The analytical error in case of minor and trace elements was found to be within $2.3 \%$ of the average value.

The analyses of Kutinga manganese ore samples show wide variation in their manganese and iron contents. Phosphorous content in these ores is very high in comparision to 
Table 2. Major, minor and trace element analyses of Kutinga manganese ores

\begin{tabular}{|c|c|c|c|c|c|c|c|c|c|}
\hline & & 1 & 2 & 3 & 4 & 5 & 6 & 7 & 8 \\
\hline $\mathrm{MnO}_{2}$ & $(w t)$ & 55.78 & 85.62 & $63.5 \mathrm{~B}$ & 51.57 & 54.59 & 66.05 & 65.66 & 57.99 \\
\hline $\mathrm{Fe}_{2} \mathrm{O}_{3}$ & & 24.13 & 0.60 & 11.68 & 28.02 & 25.34 & 14.43 & 12.52 & 18.11 \\
\hline $\mathrm{Al}_{2} \mathrm{O}_{3}$ & & 0.64 & 0.25 & 2.48 & 1.15 & 1.65 & 1.81 & 1.43 & 1.30 \\
\hline $\mathrm{SiO}_{2}$ & & 4,48 & 0.15 & 5.13 & 3.16 & 2.41 & 3.68 & 5.28 & 4.93 \\
\hline $\mathrm{CaO}$ & & 1.13 & 1,68 & 1.85 & 1.23 & 0.98 & 0.88 & 1.12 & 0.72 \\
\hline $\mathrm{MgO}$ & & 0.19 & 0.11 & 0.18 & 0.14 & 0.19 & 0.36 & 0.12 & 0.10 \\
\hline $\mathrm{K}_{2} \mathrm{O}$ & & 2.13 & 3.99 & 2.35 & 2.20 & 2.23 & 1.07 & 2.44 & 2.23 \\
\hline $\mathrm{Na}_{2} \mathrm{O}$ & & 0.25 & 0.31 & 0.23 & 0.26 & 0.25 & 0.23 & 0.25 & 0.30 \\
\hline $\mathrm{P}_{2} \mathrm{O}_{5}$ & & 0.32 & 1,08 & 0.44 & 0.35 & 1.15 & 0.37 & 0.63 & 0.80 \\
\hline $\mathrm{TiO}_{2}$ & & 0.01 & 0.01 & 0.05 & 0.05 & 0.05 & 0.01 & 0.01 & 0.02 \\
\hline $\mathrm{Li}_{2} \mathrm{O}$ & & 0.22 & 0,31 & 0.22 & 0.22 & $0.2^{0}$ & 0.14 & 0.21 & 0.25 \\
\hline LOI & & 10.42 & 5.65 & 10.57 & 10.86 & 11,06 & 11.05 & $10.2^{3}$ & 12.76 \\
\hline Total & & 99.70 & 99.76 & 98.76 & 99.21 & 100.10 & 100.08 & 99.90 & 99.51 \\
\hline $\mathrm{Cu}$ & (ppm) & 59 & 90 & 59 & 99 & 142 & 174 & 75 & 325 \\
\hline $\mathrm{Ni}$ & & 214 & 135 & 317 & 341 & 230 & 492 & 406 & 210 \\
\hline Co & & 170 & 202 & 216 & 198 & 177 & 277 & 172 & 144 \\
\hline $2 \Pi$ & & 274 & 171 & 218 & 247 & 303 & 288 & 351 & 423 \\
\hline $\mathrm{Pb}$ & & 17 & 19 & 42 & 47 & 49 & 39 & 37 & 43 \\
\hline $\mathrm{Cr}$ & & 73 & 149 & 33 & 145 & 121 & 96 & 57 & 104 \\
\hline
\end{tabular}

other deposits, e.g. Western Koira valley, North Orissa, India (Mohapatra, 1992) ; North Kanara and Chiknayakanahalli Green stone belt Karnataka, India (Machigad, 1990; Anantha Murthy and Devraju, 1990); Groote Eylandt, Australia (Varentsov, 1982); Islay, Argyllshire (Nicholson, 1988); Urkut, Hungary (Varenstov et al., 1988); Tokoro belt of Japan (Choi and Hariya, 1992) and more or less comparable with Nishikhal manganese ores, south Orissa, India (Acharya et al., 1990 and 1994) as well as manganese ores of central India (Gonditic types of M.P.- Maharastra belt ; Sahoo et al., 1982). Presence of high iron, high phosphorous and dominance of $\mathrm{CaO}$ over $\mathrm{MgO}, \mathrm{K}_{z} \mathrm{O}$ over $\mathrm{Na}_{2} \mathrm{O}$, $\mathrm{Ni}$ over $\mathrm{Co}, \mathrm{Zn}$ over $\mathrm{Pb}$ and $\mathrm{Cu}$ over $\mathrm{Pb}$ are the characteristics of Kutinga manganese ores. Similar behaviour is also reported from the gonditic manganese ores of M.P. and Maharastra, India (Mookherjee, 1961). The higher concentration of trace elements like $\mathrm{Cu}$, $\mathrm{Pb}$ and $\mathrm{Zn}$ are considered to be the diagnostic of hydrothermal and/or volcanogenic manganese deposits (Zantop, 1981; Nicholson, 1986 and 1988; Ajmal, 1990). Lower concentration of the above trace elements in these manganese ores may suggest that the contribution of hydrothermal and volcanogenic origins is minor or insignificant.

\section{Genesis of the deposit}

The genesis of this deposit is discussed briefly under source and deposition; metamorphism; granitic and pegmatitic activities and supergene enrichment.

\section{Source and deposition of manganese}

Continental erosion, volcanic activity and/ or hydrothermal process have traditionally been cited as source for most of the manganese deposits of the world. The classic problem one encounters while attributing any such source is the association of iron along with manganese. Unusual huge accumulations of either of these two or often to the mutual inclusion, have 
prompted many authors to propose volcanic activity as a probable source. However, manganese derived from the volcanogenic and/or hydrothermal sources are ruled out for this deposit because of the following facts:

a) Non-existance of rocks derived from volcanic activity in the near vicinity of the area under investigation.

b) Concentrations of $\mathrm{Cu}, \mathrm{Pb}$ and $\mathrm{Zn}$ in this manganese ores are much lower than that of hydrothermal and volcanogenic deposits (Zantop, 1981; Nicholson, 1986 and 1988; and Ajmal, 1990).

c) Absence of wall rock alteration and manganese sulphide minerals, such as alabandite donot indicate this deposit to be of hydrothermal origin (Roy, 1981).

Occurrence of well defined manganese band having same strike and dip with that of the country rocks (metasediments, e.g. khondalite and quartzite) having signatures of deformation on both, strongly suggest for a metasedimentary parentage for this deposit. Manganese ore bodies appear to be confined to a definite stratigraphic horizons in khondalite suite of rocks in this part of Eastern Ghats complex. Continental erosion appears to be the most probable source. This fact is supplemented by the $\mathrm{Na}$ vs. Mg plottings of the manganese ores which lie in the freshwater field of Nicholson (1988; Fig. 14). The scatter of plots of $\mathrm{Na}$ against $\mathrm{Mg}$ clearly distinguishes manganese oxides deposited in marine, shallow marine and fresh water environments (Nicholson, 1988).

In. Kutinga deposit, both metamorphic mineral assemblages (relics of primary minerals such as hausmannite and spessartite) and their supergene derivaties (secondary manganese and iron minerals like cryptomelane, pyrolusite, psilomelane, lithiophorite, goethite) have been observed. However, no mineralogical and textural features are preserved to indicate that these primary oxide and the sili-

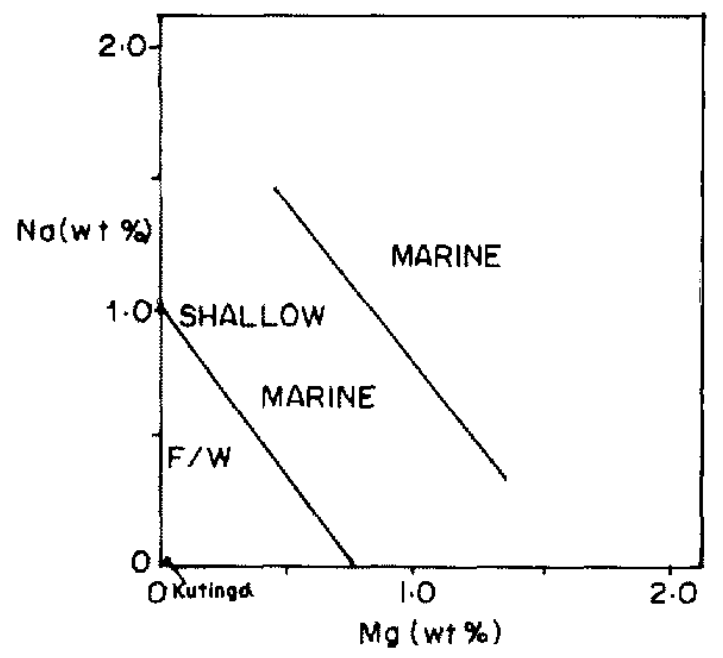

Fig. 14. Kutinga manganese ore sample ( plotted on the discrimnation diagram of Nicholson (1988). F/W-Fresh Water.

cate minerals existed in the original sediments (syngenetic minerals). It is unlikely that these minerals themselves existed in the original sediments and simply recrystallized during metamorphism.

The existence of oxide and silicate minerals only in the Kutinga manganese ores sug. gest that a oxide facies was dominating (without any manganese carbonates or manganese sulphides) during original sedimentation. Absence of any manganese carbonate mineral further indicates that the deposition of the ores took place under highly oxidising environments. Presence of different silicates in the manganese ores indicates that the manganiferous sediment which was rich in iron probably also containcd abundant admixtures of sand and/or clay.

The mode of transportation of Fe and $\mathrm{Mn}$ and their deposition under oxidising conditions has long been known (Rankama Sahama, 1950; Krauskopf, 1957). Fe and Mn might have been transported as finely divided particles in river waters, as adsorbed compounds on clay particles, as sols, gels and so on. Manganese com- 
pounds are soluble in neutral and acid solutions (Sivaprakash, 1980) while not so soluable under alkaline conditions. $\mathrm{Fe}$ is more readily precipitated than $\mathrm{Mn}$ under suitable Eh-pH condition. $\mathrm{Mn}$ and $\mathrm{Fe}$ might have been precipitated in the form of compounds such as $\mathrm{Mn}(\mathrm{OH})_{4}, \quad \mathrm{MnO}_{2}, \quad \mathrm{Fe}(\mathrm{OH})_{3}$, and $\mathrm{Fe}_{2} \mathrm{O}_{3}$. $\mathrm{Mn}(\mathrm{OH})_{4}, \quad \mathrm{MnO}_{2}$ sols and gels being negatively charged readily adsorb cations such as $\mathrm{K}$ and Ba (Rankama and Sahama, 1950). Such manganese precipitates with adsorbed materials during diagenesis could transform into oxides of higher valency states such as cryptomelane, psilomelane etc.

\section{Metamorphism}

After deposition and diagenetic changes, the manganese minerals of higher valency states were metamorphosed under granulite facies conditions along with conformable, psammitic and pelitic sediments of Eastern Ghats. Metamorphism of manganese oxides is relatively a simple process. With an increase in pressure and temperature during metamor. phism, the manganese minerals of higher valency states were transformed to oxides of rela. tively lower valency (Roy, 1981), and this is essentially a case of isochemical metamorphism except for any redox changes. Temperature, pressure and oxygen fugacity are the important parameters in controlling the manganese oxides/silicates stability boundaries during metamorphism. The manganese formation along with the associated country rocks have been affected by polyphase metamorphism and deformation (Acharya and Dash, 1984). Quartzofeldspathic neosomes pervade and obliterate parts of the other rock types including manganese bands and occur as laminae, dis. crete patches, stromatitic bands, veins and dykes. Some are coarse grained quartz-feldspar-mica pegmatites.

The presence of some of the primary minerals can be used to estimate their tempera- ture of formation. For instance, hausmannite could result from the direct transformation of an early formed $\mathrm{Fe}^{-\mathrm{Mn}}$ hydroxide, (which donot transform to intermediate oxides such as bixbyites) at $600^{\circ}-750^{\circ} \mathrm{C}$ (Okada, 1960) which is in agreement with the temperature of metamorphism. The temperature and pressure conditions of metamorphism of Eastern Ghat rocks in parts of Orissa is determined to be $>650^{\circ} \mathrm{C}$ and $>6 \mathrm{~Kb}$ (Park and Dash, 1984 ; Dash et al., 1987). The granulite facies metamorphism is followed by retrograde metamorphism.

\section{Supergene enrichment}

During the post metamorphic period, prolonged exposure of the deposit to atmospheric oxygen and percolation of meteoric waters has caused the primary minerals to undergo supergene alteration. While all the primary minerals have undergone supergene alteration, most of the primary manganese oxide minerals are totaly obliterated by weathering and supergene process. However, the manganese silicates like spessartite is partly affected by weathering and supergene process. Alteration of manganese garnet is intense where fractures and microfractures are present. Under supergene condition and because of strong oxidation effects, the manganese oxides of lower valency states (primary minerals) might have transformed to higher valency oxides, e.g. cryptomelane, psilomelane, pyrolusite etc. (Sivaprakash, 1980; Acharya et al., 1990). Lithiophorite might have produced by a low temperature reaction of clay minerals and primary manganese oxides during the weathering process (Ostwald, 1980, 1988). Presence of chalcedony showing colloidal texture is also related to weathering process.

\section{Discussion and conclusion}

Mode of occurrence, mineralogy, texture and chemical characters of Kutinga manganese ores suggest their formation as chemical precip- 
itates, and the source of which appears to be continental erosion. Manganese formation along with the country rocks have been metamorphosed under granulite facies conditions, affected by granitisation and later subjected to supergene enrichment to give rise to the present mineral assemblages.

A direct relationship appears to exist between phosphorous content and metamorphic grade of Indian manganese ore deposits. Low or unmetamorphosed manganese ores contain very small amounts of phosphorous whereas the high grade metamorphosed ores contain higher amounts of phosphorous (Krishnan, 1982). This is in agreement with the fact that the Kutinga deposit which has undergone granulite facies metamorphism also contains high amounts of phosphorous. Phosphorous in the Kutinga ores is present as fine apatite crystals within the silicate gangues and also adsorbed with various manganese and iron phases. The original manganiferous sediments probably contained some amount of phosphorous (Sivaprakash, 1980) and some more phosphorous in the form of apatite might have been introduced into the manganese ores through granitic and pegmatitic activities (Acharya et al., 1990), preceeding the supergene enrichment. A primary manganese silicate mineral, spessartite contains small amounts of phosphorous. During supergene enrichment, the phosphorous content in the secondary manganese phases have been relatively increased (Acharya et al., 1994). The hydrous oxide of iron and manganese, which has probably derived from the primary manganese oxide and silicate minerals, contains highest amount of phosphorous $(2.05 \%$ $\left.\mathrm{P}_{2} \mathrm{O}_{5}\right)$. Goethite, cryptomelane, psilomelane are in decreasing order of phosphorous content.

These ores are amenable to removal of silica and silicates by physical beneficiation (magnetic or gravity routes). Removal of iron by this process is not possible because of fire size and intricate association of goethite with manganese ore minerals. As the apatite is in small quantity and majority of the phosphorous is in adsorption with manganese and iron phases, the ore will neither respond well to removal of phosphorous by physical beneficiation nor to acid leaching methods. However, this ore is likely to respond well to dephosphorisation by roast-alkali leaching methods (Banerjee et al., 1990).

Acknowledgements: The authors are thankful to the staff of USIC, Roorkee and Dr. B.B. Nayak and Dr. B.N. Sahoo, Scientists, RRL, Bhubaneswar for help in electron probe and chemical analyses respectively. Thanks are due to Prof. H.S. Ray, Director, RRL, Bhubaneswar for his keen interest in this work and permission to publish this paper. One of the authors (DSR) is grateful to CSIR, New Delhi for financial support in the form of a Fellowship.

\section{References}

Acharya, B.C. and Dash, B. (1984), Graphite in Eastern (Thats Precambrian migmatites, Oris. sa, india. Trans. Roy. Soc. Edinburgh, Earth Sci. 75, 391-406.

Acharya, B.C., Rao, D.S. and Sahoo, R.K. (1994), Phosphorous in the siliceous manganese ores of Nishikhai, Orissa. Ind. J. Geol., 66(1), 15m 23.

Acharya, B.C., Rao, D.S., Sahoo, R.K. and Dash, B (1990), Nishikhal manganese deposit. Orissa. J. Geol. Soc. Ind., 36(6), 644-653.

Ajmal, M. (1990), Trace element study of manga. nese ores of the Barbil area, Keonijhar district. Orissa, India. Mineral. Deposita, 25, 160-162.

Anantha Murthy, K.S. and Devaraju, T.C. (1990), Mineralogy, geochemistry and genesis of manganese ore deposits of Chiknayakanahalli Greenstone belt, Karnataka. Studies in Earth Sci., Prof. C. Naganna felicitation vol., Bangalore University, 111-122.

Banerjee, G.N., Kanungo, S.B. and Dey, DN. (1990). Dephosphorisation of manganese ores by alkali roast leaching process applying 
agglomeration technique. Nat. Sem on Ferro Alloys Changing Scenario, held on 27th Jan. Bhubaneswar, 12.1-12.5.

Choi, J.H. and Hariya, Y. (1992), Geochemistry and depositional environment of $\mathrm{Mn}$ oxide deposits in the Tokoro belt, North eastern Hokkaido, Japan. Econ. Geol., 87, 1265-1274.

Dash, B., Sahu, K.N. and Bowes, D.R. (1987), The geochemistry and original nature of Precambrian khondalites in the Eastern Ghats, Orissa, India. Trans. Roy. Soc. Edinburgh, Eurth Sci., 78, 115-127.

Deer, W.A., Howai, R.A. and Zussman, J. (1963), Rock forming minerals, 1 \& 5 . Longman, London.

Fermor, L.L. (1909), The manganese deposits of India. Mem. Geol. Surv. Ind, 37.

Graham, J. (1973), Phosphorous in iron ore from the Hamersley Iron Formation. Proc. Aus. tralas. Inst. Min. Metall., 246, 41-42.

Indian Minerals Year book (1992), Indian Bureau of Mines, Nagpur, 2, 548-549.

Krauskopf, K.B. (1957), Separation of manganese from iron in the sedimentary processes. Geochim. Cosmochim. Acta, 62, 61-84.

Krishnan, M.S. (1982), Geology of India and Burma. CBS publishers and distributors, India, pp. 152.

Machigad, B.S. (1990), Iron and manganese deposits of north Kanara district, Karnataka. Studies in Earth Sci., Prof. C. Nuganna felicitation vol., Bangalore University, 58-63.

Mohanty, B.K. (1991), Mineral development in Orissa during 1990's Prospects and constraints. Proc. of 3rd Int. Symp. on Beneficiation and Agglomeration, held during 16-18 Jan., Bhubaneswar, 43-50.

Mohapatra, B.K. (1992), Mineralogical and geochemical studies of the Iron Ore Group around "Barsua, Kalta, Koira" region, Orissa, India, with special reference to associated ore deposits. Unpublished Ph.D. Thesis, Utkal University, Orissu, India.

Mookherjee, A. (1961), Distribution of minor elements in the Gonditic manganese ores and its geochemical significance. Econ. Geol., 56, $723 \% 729$.

Nicholson, K. (1986), Mineralogy and geochemis- try of manganese and iron veins, Arndilly, Banffshire. Scott. J. Geol, 22, 213-224.

Nicholson, K. (1988), An ancient manganese-iron deposit of fresh water origin, Islay, Argyllshire. Scott, J. Geol., 24, 175-187.

Okada, K. (1960), Thermal study on some todoro kites. J. Min. Pelr. Econ. Geol, 45, 49-53.

Ostwald, J. (1980), Aspects of the mineralogy, petrology and genesis of the Groote Eylandt manganese ores. In Geology and geochemistry of manganese ores, 2, (I.M. Varentsov and G. Grasselly Ed.) Schweizerbart'sche Verlags. buchhandlung, Stuttgart, 149-182.

Ostwald, J. (1988), Mineralogy of the Groote Eylandt manganese oxides: A review. Ore Geol. Reviews, 4, 3-45.

Park, A.F. and Bash, B. (1984), Charnokite and related neosome development in Eastern Ghats, Orissa, India: Petrographic evidence. Trans. Roy. Soc. Edinburgh, Earth Sci., 75, 341352.

Rankama, K. and Sahama, T.G. (1950), Geochemistry. 912-950, Chicago University Press.

Roy, S. (1981), Manganese deposits. pp. 1 458, Academic press, London.

Sahoo, R.K., Kanungo, S.B. and Natarajan, R. (1982), A note on the occurrence of phosphorous in manganese ores of central India and its liberation during size reduction. Ind. Min. \& Engg. J., 25-32.

Sivaprakash, C. (1980), Mineralogy of manganese deposits of Koduru and Garbham, Andhra Pradesh, India. Econ. Geol., 75, 1083-1104.

Varentsov, I.M. (1982), Groote Eylandt manganese oxide deposits, Australia I: General characteristics. Chem. Erde, 41, 157-173.

Varentsov. I.M., Grasselly, Gy., Szabo, Z. (1988), Ore formation in the early Jurassic basin of Central Europe: Aspects of mineralogy, geochemistry and genesis of Urkut manganese deposit, Hungary. Chem. Erde, 48, 257-304.

Vogel, A.I. (1961), A text book of quantitative inorganic analysis. Longman, London.

Zantop, H. (1981), Trace elements in volcanogenic manganese oxides and iron oxides in the San Francisco manganese deposits, Mexico. Econ. Geol., 76, 545-555. 